Jurnal Entrepreneur dan Entrepreneurship, Vol. 9, No. 2, September 2020, 111-122

ISSN 2302-1802 print / ISSN 2580-9393 online

\title{
DEVELOPMENT OF BUSINESS MODEL DIGITAL FRACTION PROPERTY INVESTMENT
}

\author{
I Gede Putu Rahman Desyanta \& Gede Sri Darma \\ Universitas Pendidikan Nasional, Denpasar, Bali, Indonesia
}

\begin{abstract}
Investing a property or real estate could be a challenge for Millennials generation. The increase in property prices is not in line with the increased of minimum wage that makes Millennials only afford to rent the property. To having an investment in property need more time in legal procedure, sometime need more than months. Fraction Property investment is a concept of investing property together. Separate the property in other format of digital assets distributed it to all more than one party. To implement this concept need to has a suitable business model and technology. Rising of industrial revolution 4.0, introduce the world with Blockchain Technology. The research is aiming to give better picture of new business model of investing on a property based on blockchain technology. With right business models, millennials generation will have another methods of investment on a property, that secure, easy and digital.
\end{abstract}

Keywords: blockchain, business models property, fraction property, millennials

\section{INTRODUCTION}

The increasing number of people encourages the demand for property. Following the Central Bank of Indonesia data, the demand index of property in Indonesia from 2016 to 2018 continues to increase.

From 2016, every quarter up to the year 2018 commercial property Demand index increased from 126.63 to 133.72 . Requests for the property that can be purchased remain larger than the rent. Property inventory in Indonesia experienced a significant increase in the 4th quarter of the year 2018. This increase reached $8.58 \%$ from the previous year. From 2016 to 2017 the growth of property business in Indonesia experienced insignificant growth, even less likely to decline. But starting in 2018, the growth of the property begins again. This property's growth in demand encourages property companies to continue to prepare property inventory.

Property prices in Indonesia continue to increase over the last 3 years. The growth per year of the property could reach 17\%. With consistent value continues to increase annually.

Tabel 1 Commercial Property Demand Index

\begin{tabular}{|c|c|c|c|c|c|c|c|c|c|c|c|c|}
\hline \multirow[t]{2}{*}{ Remark } & \multicolumn{4}{|c|}{2016} & \multicolumn{4}{|c|}{2017} & \multicolumn{4}{|c|}{2018} \\
\hline & 1 & II & III & IV & 1 & II & III & IV & 1 & II & III & IV \\
\hline $\begin{array}{l}\text { Commerci } \\
\text { al Property } \\
\text { Demand } \\
\text { Index }\end{array}$ & $\begin{array}{c}126.6 \\
3\end{array}$ & $\begin{array}{c}126.9 \\
9\end{array}$ & $\begin{array}{c}127.5 \\
7\end{array}$ & $\begin{array}{c}128.0 \\
8\end{array}$ & $\begin{array}{c}128.5 \\
9\end{array}$ & $\begin{array}{c}128.8 \\
8\end{array}$ & $\begin{array}{c}129.1 \\
6\end{array}$ & $\begin{array}{c}129.5 \\
8\end{array}$ & $\begin{array}{c}131.0 \\
5\end{array}$ & $\begin{array}{c}131.4 \\
3\end{array}$ & $\begin{array}{c}131.9 \\
8\end{array}$ & $\begin{array}{c}133.7 \\
2\end{array}$ \\
\hline Renting & 70.73 & 9.13 & 71.3 & 2.2 & 2.20 & 3.5 & 75.53 & & 74.01 & 75.12 & 76. & 77.02 \\
\hline Selling & $\begin{array}{c}127.4 \\
1\end{array}$ & $\begin{array}{c}127.8 \\
6\end{array}$ & $\begin{array}{c}128.3 \\
4\end{array}$ & $\begin{array}{c}128.7 \\
8\end{array}$ & $\begin{array}{c}129.4 \\
7\end{array}$ & $\begin{array}{c}129.7 \\
0\end{array}$ & $\begin{array}{c}129.9 \\
3\end{array}$ & $\begin{array}{c}130.4 \\
8\end{array}$ & $\begin{array}{c}131.9 \\
7\end{array}$ & $\begin{array}{c}132.3 \\
2\end{array}$ & $\begin{array}{c}132.7 \\
6\end{array}$ & $\begin{array}{c}134.5 \\
5\end{array}$ \\
\hline
\end{tabular}

Source: Central Bank of Indonesia

*Corresponding Author.

e-mail: igp.r.desyanta@gmail.com 
I Gede Putu Rahman Desyanta \& Gede Sri Darma / Development of Business Model Digital Fraction

Property Investment / JEE, Vol. 9, No. 2, September 2020, pp 111-122

Property investment provides an investment certainty for its owner. Besides, the visible asset form makes the property buyers quicker to adapt to this type of investment. Also, owning the property has the opportunity to earn extra income by renting the property. Property price increases also lead to a high cost of owning a property.

The Bank has provided credit services for property ownership, but still, the property prices remain unreachable especially the millennials that just started to work and start their lives. Due to the new entry of this generation into the workforce, they have not had enough funds to be able to buy the property.

According to Kompas.com data, in 2018, millennials generation are 18 to 38 years old today. The compass also mentions that $34.54 \%$ of the population of Indonesia are millennials. Those show that more than a quarter of the people in Indonesia is millennials. The World Economic Forum (WEF) in 2015 than predicted that Indonesia in the year 2020 will be the 8 th Economic force in the world. This statement is driven by economic policy and also the growth of the number of millennials in Indonesia. Report that the economics drivers of Indonesia are the millennials.

One of the problems faced by millennials is related to real estate ownership. A Survey of rumah123 conducted in 2017, shown on detik.com, found that $95 \%$ of millennials would not have a home. Only 5\% of the total millennials can buy a house. It is because of the extravagant lifestyle of millennials. Besides, the minimum wage growth and the yearly property prices are also a problem.

The average minimum wage rate in Indonesia is only up to $10 \%$ meanwhile, the growth of property prices every year averages up to
$17 \%$. It is a problem for millennials to be able to have a home, especially for investing in property. For example, if the price of the house is 600 million rupiahs, then the millennials should have a salary of 200 million per year or 16 million a month. Rumah123 surveys found out that only $4 \%$ of total Millenials have an income of more than 16 million per month.

The inequality between the average increase in the minimum wage with property growth in Indonesia requires an alternative solution for the generation of millennials to invest and possess property. Not only for generations of millennials but also other Indonesian people. Having a shared property investment is still the right solution however, these existing business models still need more money.

The ability of the Blockchain technology, provide opportunities for digitizing property assets. Each property can be translated into a particular asset that is built in the blockchain data structure. This provides opportunities for Millenials to have more affordable assets with the digitalization of the asset together.

\section{METHOD}

This research focusing on Satu Bata platform, a startup that just on going to obtaining listed in OJK infinity office. This research data come from both primary and secondary data. Primary data obtained by deep interview to the parties directly related to digital fraction property investment practitioners, blockchain technology expert and regulatory department of financial technology. Secondary data obtained from several source such as literature review, annuals report, website etc. This research uses qualitative data analysis techniques with the stages of data collection, data reduction, data 
display and drawing conclusions and data verification. To understanding the environment in Indonesia, PEST analysis is conducted. Understanding the political, economics, social and technology aspect that can affect the business. Using Business Model Canvas, the business models is mapped in 9 component. This analysis based on the uses case of satubata platform. SWOT analysis will be used to understand internal and external factor that can direct us to strategy of this business model that sustain.

\section{RESULTS}

Until now, there has been no definite definition associated with the business model. Business model is a story that explains how the company works (Casadesus-Masanell \& Ricart, 2010). In this case, the story in question is a logic in running the business. Every business has its own logic in running the process so that it can make a profit or achieve a vision defined by its founder.

The technological developments in this digital era are delivering us in the era of Revolution 4.0 industry. The revolution is characterized by the growing use of Big Data technology, artificial intelligence, the Internet of Things and Blockchain. According to Christensen, J. V. (1997), Encouraging the company not only meet the needs of its own business but continue to innovate to meet the needs of the future.

Disruptive makes companies bold in destroying the habits they do. New logic must be built into business so that new value occurs and bring company to maximize its position in competition map. The 4.0 Industrial Revolution encourages companies to build new business models where they lead to smart products and services(Ibarra, Ganzarain, \& Igartua, 2018).
According to Ibarra, Ganzarain \& Igartua (2018), new business model utilizes new technology that can assist in building products that provide more value and a unique service to its customers.

Tabel 2 Change of Business Mode Component

\section{Value Delivery}

- Smart Products that continually collect information from customers, the environment and about its performance

- Innovation in Associated services: Predictive maintenance, activation of product upgrades, booking spares, etc.

- Co-Creation: Customer is part of the process of creating value

- Direct Relationship: Between the firm and the customers

\section{Value Creation}

- New physical, human, and intellectual resources are required

\section{Value Capture}

- New Revenue Stream: Dynamic pricing, pay-per-use, performancebased revenue, etc.

Source: (Ibarra et al., 2018)

Business change in this model affects many aspects in human life in both social, legal and economic areas. (Prasetyo \& Trisyanti, 2018). The implementation of new technologies and shifts in business models can provide opportunities for resolving problems that are hard to solve with the old technology.

\section{PEST Analysis}

Business model Digital Fraction Property Investment is a business model that leads to financial services. The things that govern the rules and how the development of financial and investment services become important. In addition, in terms of its business development, the 
I Gede Putu Rahman Desyanta \& Gede Sri Darma / Development of Business Model Digital Fraction

Property Investment / JEE, Vol. 9, No. 2, September 2020, pp 111-122

company that is engaged in businesses of this model is a digital pilot or startup company.

\section{a. Political aspects}

During the distruptive period, Indonesia was led by President Joko Widodo (JOKOWI). In this era, significant technological growth occurred. The first period of the policy is on infrastructure development. This gives SMES an advantage to continue growing. In 2018, in Databoks(2019a) There are 992 startups in Indonesia. Startups that have a creative business, built by the Creative Economic Agency (BEKRAF) initiated by the Government to ensure the growth of this startup can build a better economic Indonesia.

The development of this startup is also an opportunity for the Ministry of Finance and Bank Indonesia. With a good technological adaptation, the opportunity to improve financial inclusion and financial literacy can be done to the far reaches of Indonesia by developing the startup of financial services and payments.

In 2018, OJK established infinity (Indonesian Center Of Financial Technology) which aims to build a fintech ecosystem to be part of the national financial system that is beneficial for society and the country. OJK Infinity is tasked to become a collaboration platform between industries, regulators, governments, academics and other innovation hubs. The basis of Infinity establishment is regulation OJK number 13/POJK. 02/2018 which describes the digital financial innovations in the financial services sector. This Regulation regulates the ordinances and rules for the establishment of digital financial innovations(OJK, 2018).

The political situation in Indonesia at this time is encouraging innovation. Digital financial innovation is one of the main focuses to ensure improved financial literacy and inclusion. In this case, the direction of the political policy is marked by law and the Government's policy supports it. Other things to note are tax policy as well as consumer protection as well as their data.

\section{b. Economic aspects}

Indonesia's economic growth of 4 years (2016-2019) is still around 5\%. It puts Indonesia in a position as a country with good economic growth in southeast Asia.

Stages of business cycle in Indonesia according to Kartiasih, Fitri (2019) In his research titled "Inflation and the political business cycle in Indonesia", theoretically the political business cycle has stated that inflation will drop in the beginning of the reign. However, this study mentions that it is not so happening in Indonesia. This happened only in the early days of the reign of President Megawati Sukarno Putri and President Joko Widodo. At the time of the inflation election will decline and increase in post-election of $1.15 \%$. Kartiasih(2019) also explained that during the period of the regime was 5 years, expansion of economic growth occurred at the end of the government period, but did not happen during the 2nd period of Susilo Bambang Yudhoyono (SBY) reign. In this study shows that the business cycle in Indonesia occurs from the monetary side.

Fajar, Muhammad(2017), In his research entitled "Indonesia's Business cycle spectral analysis," said that the business cycle in Indonesia is not a pure periodic component or recurrent but not periodic. This indicates that the business cycle in Indonesia leads to certain situations. Variations of this business cycle are not regular and vary between 13 to 67 quarters. 
The two researchers showed that the business cycles in Indonesia were quite varied, but were heavily influenced by the monetary and political movements that occurred in Indonesia.

Demographic Indonesia which has a millennials of $37 \%$ productive, with an education level S1 has an average income of Rp. 3.2 million. While the Diploma has an education level has an average income at Rp. 2.9 million. By the average this income will have an impact on the consumptive level of millennials depending on urban areas or not. But if averaged income from all the millennials in all levels of education, the average of Rp. 2,150,223(Budiati et al., 2018).

It can be concluded that Indonesia's economic growth is highly dependent on the political situation in Indonesia. The success of the government will deliver good economic growth. In addition, the electoral cycle should be considered because it will directly or indirectly affect the purchasing power of the community. If targeting millennials, the most important thing is to adapt to the income. The average income of millennials is relatively small, requiring a good pricing strategy to be well received by millennials.

\section{c. Social aspects}

According to Databoks (2019b) In the year 2019 , population in Indonesia reached 266 mil- lion. Where more than $60 \%$ of the total population is a generation of millennials (generation $\mathrm{Y}$ and Post millennials). The magnitude of the number of millennials the more years will increase has a very significant social impact.

There are 6 common characteristics of this generation (Farrell \& C., 2014) i.e. (1) Ability to multi-tasking, (2) desire for regularity (structured), (3) focus on achievement or Target, (4) Fluent technological use, (5) Team oriented and (6) seeking attention and feedback. These 6 characteristics form a shift in cultures in every sphere of life.

According to tirto.id(2017), Spending of millennials generations to make vacation trips, doing outdoor activities such as eating, walking and hanging out much bigger than generation $\mathrm{X}$ and Baby boomers. The portion of spending on this lifestyle is enormous for generations of Millennials.

On 17 Nov 2019(Wikipedia, 2019), The world discovers a new type Corona virus in Wuhan province, CHINA. This Virus is called COVID-19. The rapid spread of this virus caused many countries to close their borders to Lockdown. The closure is an impact on economic decline in all parts of the country even in Indonesia.

The lifestyle changed from hedonistic to Home Alone (\#dirumahaja). The movement at home alone was frustrated by the government

Table 3 Indonesian Population based on Generation

\begin{tabular}{lcccc}
\hline \multicolumn{1}{c}{ Generation } & Male & Female & Total & $\mathbf{( \% )}$ \\
\hline Mature $(<1946)$ & $5,574,800$ & $4,452,400$ & $10,027,200$ & $3,76 \%$ \\
\hline Baby Boomers (1947-1964) & $15,290,700$ & $15,071,600$ & $30,362,300$ & $11,38 \%$ \\
\hline Generasi Xers (1965-1980) & $26,199,700$ & $26,483,100$ & $52,682,800$ & $19,73 \%$ \\
\hline Generasi Y/NetGen (1981-1995) & $42,347,500$ & $43,184,000$ & $85,531,500$ & $32,04 \%$ \\
\hline Post Millenials (>1995) & $43,473,600$ & $44,834,500$ & $88,308,100$ & $33,08 \%$ \\
\hline Total & $132,886,300$ & $134,025,600$ & $266,911,900$ & \\
\hline
\end{tabular}

Source: Databoks, 2019b 
I Gede Putu Rahman Desyanta \& Gede Sri Darma / Development of Business Model Digital Fraction

Property Investment / JEE, Vol. 9, No. 2, September 2020, pp 111-122

in Indonesia to make a personal restriction to prevent the virus from spreading rapidly in Indonesia. This movement encourages the use of an online platform much more increasing. Nielsen Research(2020), In the surveillance conducted 24-29 February 2020, showed that $67 \%$ of retail entrepreneurs have developed an offline platform to online and $60 \%$ of them develop home delivery.

\section{d. Technology aspect}

According to Databoks (2017), In January 2017, mobile users registered in Indonesia recorded 371.4 million people where the population of Indonesia at the time was 262 million. APJII Survey, Internet Service Provider Association of Indonesia (2018), in 2018, indicating that there were $171,17(64,8 \%)$ million people from the total population of Indonesia using the Internet. In this case the growth of Internet users in 1 year amounted to $10.12 \%$. When viewed from the average population growth of $0.63 \%$ per year, the growth penetration of Internet users reaches more than 10 times annually. This suggests that the literacy of the importance of Internet use goes well in Indonesia.

On 14 October 2019, President Joko Widodo inaugurated the operation of Palapa ring project in Indonesia (Maritim, 2019). This Palapa Ring project is a telecommunication infrastructure project in the form of fiber optic development throughout Indonesia for 36,000 kilometers. This network is intended as a network backbone that can be used by all telecommunication services providers in Indonesia. With the Palapa Ring, the government hopes to increase the penetration of Internet use, increasing access to telecommunications and the Internet and can reduce the cost of Internet use in Indonesia.

\section{Blockchain Implementation in Fraction Prop- erty Investment}

This Blockchain method was first introduced by Satoshi Nakamoto (2016) In his journal titled "Bitcoin: A Peer-To-Peer Electronic Cash System". In this journal, Satoshi Nakamoto explained about the omission of the Middle man or intermediary in conducting transactions.

Blockchain technology builds every data into blocks of data connected to each other. Blockchain builds a large network called a node. Each task node stores the same data with the same code or a similar hash. Each node will verify each transaction that occurred. Blockchain has its own characteristics that provide benefits in its implementation. According to Zeng Z. et al. (2018) There are 4 Blockchain characteristics:

Decentralization: In banking transactions, when conducting transactions require an intermediary agent to verify the transaction. This is called centralization. Centralization is often an obstacle, the verification period takes a long time and is sometimes unsafe. In this case, the blockchain allows making transactions from one point to another without an intermediary agent. Each transaction will be witnessed by all nodes on all networks and simultaneously verified together.

Persistency: Any transaction occurring on the blockchain network will be authenticated and recorded in a block distributed to all nodes on that network. This makes it difficult for counterfeiting to occur. Each block is broadcast to all nodes and monitored and validated simultaneously so that it is difficult to manipulate the data.

Anonymity: Blockchain allows the occurrence of transactions without having to open all the identity of transaction actors. Instead of storing centralized data on one server or party, data is stored on the actual owner and is only accessible if needed and permitted. 
Auditability: Any transactions that occur on the blockchain are recorded and stamped with the time, so that each transaction can be monitored backwards. This makes it easier to monitor transactions that occur.

Blockchain technology has the potential to be developed to be a technologi enabler. The implementation of this technology is closely linked to cryptocurrency but in Uganda, Blockchain is used to assist in tackling corruption (Ahishakiye, Wario, \& Niyonzima, 2018).

In the business development of the digital model fraction property investment, Blockchain assists in ensuring the process of ownership and transactions of digital assets constructed from the value of the property used.

In Fraction Investment, proof of ownership and rules in the use of assets shall be conducted jointly and approved jointly. Joint ownership contracts are passed in front of related officials so that they have protection and legal force in certain countries or territories.

\section{Smart Contract}

Term Smart contract was first mentioned by Nick Szabo (1997), by Karamitsos, Ioanis, et al. (2018) defined as the programmatic code identified by the address on the Blockchain network.

Ethereum is one of the blockchain applications used to build smart contracts. This application is common and the development of this application is done by the blockchain community. In this application the process of smart contracts is done in the following 4 processes:

Block Validation: This process is the process of validating blocks.

Network Discovery: This process is usually done for new nodes that will be logged in the Blockchain network.
Transaction Creation: This process allows the user to make transactions and allow smart contracts to create events and messages.

Mining: This process is a special code search process or mining and tells all the blocks will be new blocks.

In Fraction property Investment, each property has its own smart contract. In this case the smart contract will set the transaction protocol of the property for each user.

\section{BATA as a Digital Asset}

Fraction Investment which has a good legal basis, will reduce the risk for each investor. But because ownership is divided into several parties, the income generated by the asset will be divided into several registered investors.

In the process at platform use BATA as the identifier property. Ownership of the number of BATA is a sign of ownership of its investment in the property. Each property has its own procedures and protocols against the joint-agreed BATA transactions. Smart contracts serve as transaction protocols one property has one smart contract, so the platform allows to list many types of properties with different schemes.

BATA transactions are performed between the property owner/BATA owner and other users. Each transaction will be contracted in the system.

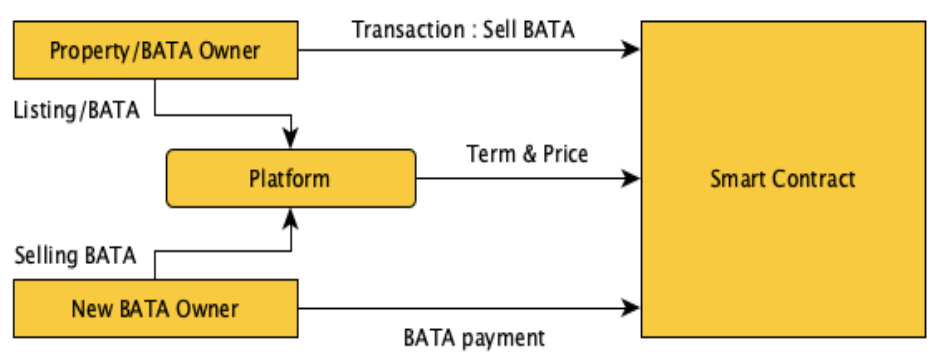

Figure 1 Transaction Process on platform SatuBata 
I Gede Putu Rahman Desyanta \& Gede Sri Darma / Development of Business Model Digital Fraction

Property Investment / JEE, Vol. 9, No. 2, September 2020, pp 111-122

Property owners or BATA owners will do the listing on the platform, the owner of a new BATA or new user chooses the property and decides to buy the sold BATA. Once the agreement is done then the system will make a new contract according to the agreement of the transaction. Each party will be given a private key to access the contracts made.

\section{Business Model Canvas}

According to OJK regulation number 13 year 2018 regarding digital financial innovation,

Table 4 Business Model Digital Fraction Property Investment

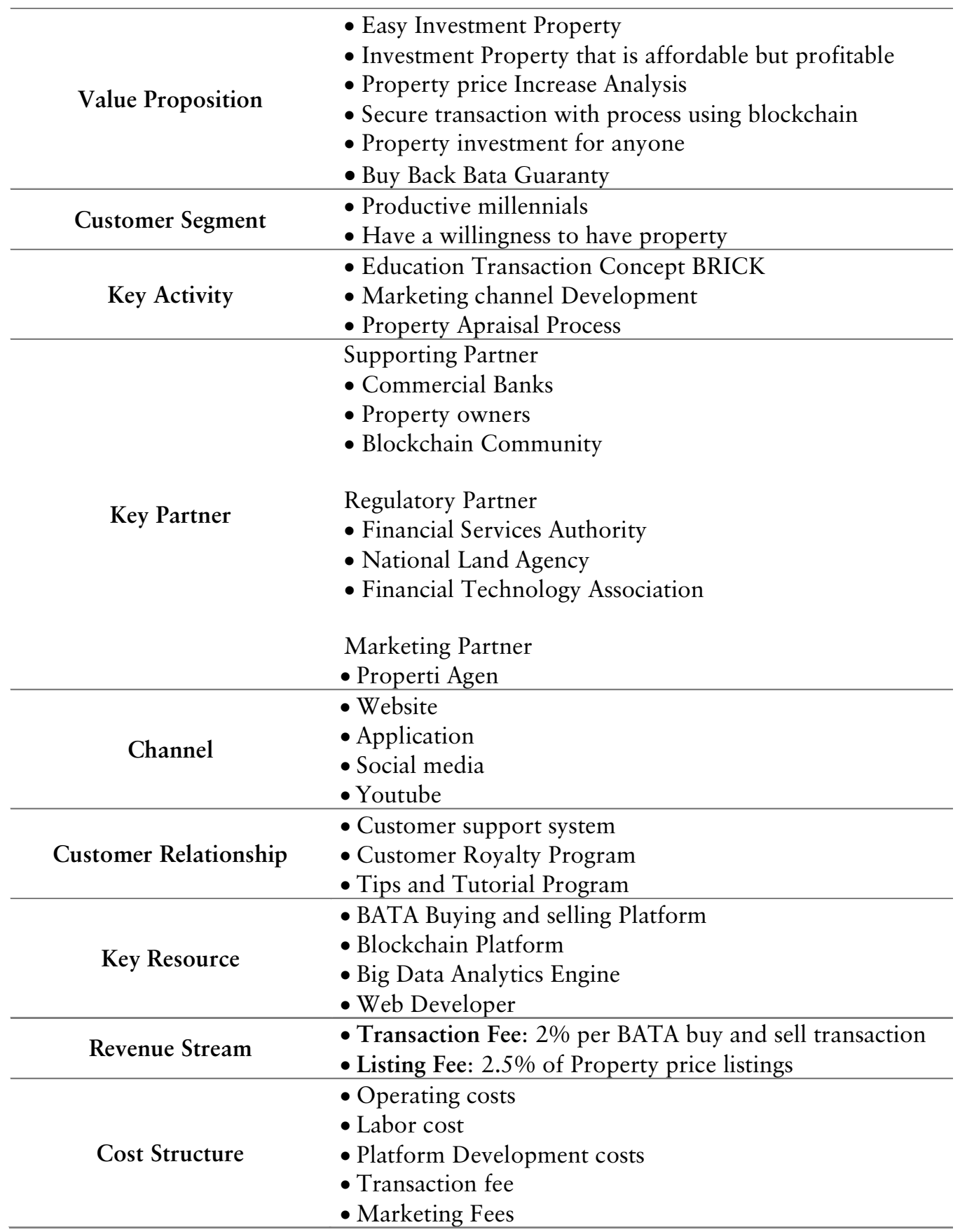


digital financial platform has focus on financial services. In this case, the platform is stated that it is not allowed to have the property to be sold. It is also confirmed from the OJK in the interview process.

In the process of selling and purchasing BATA, the platform earns $2 \%$ of every transaction occurring.

\section{Simulation:}

100 BATA $x$ Rp $100.000 *=10.000 .000$

Fee Platform: $10.000 .000 \times 2 \%=200.000$

The fees charged in the transaction:

$10.000 .000+200.000=10.200 .000$

\section{Description:}

* is a value of 1 scratch BATA

The Platform also earns a fee for each listing property. Any property that enters the listing will be charged $2.5 \%$ of the property's value after the Bank's apraisal.

\section{Simulation:}

If there are 1 properties that are listed, then the BANK partners shared platform will do appraisal property value. Assumed property value is 10 billion Rupiah. Then the FEE calculation as follows:

Property Value $\mathrm{x} 2,5 \%=\mathrm{Rp} 10.000 .000 .000$

$$
\mathrm{x} 2.5 \%=\mathrm{Rp} 250.000 .000
$$

Property value to be used as BATA:

$\operatorname{Rp} 10.000 .000 .000+\operatorname{Rp} 250.000 .000=$

$$
\text { 10.250.000.000 }
$$

Number of BATA marketed:

Rp 10.250.000.000 : Rp 100.000

$$
=102.500 \text { BATA }
$$

\section{SWOT Analysis}

Table 5 SWOT Digital Fraction Property Investment

- The investment mechanism is quite simple

- Very affordable investments

- Using the latest technology

- Security of transactions is more secure

- Investment prices continue to increase following property conditions

- Getting other incentives from property results

- Business models include very new and need education to market

- Requires a large investment fee for platform development

Weakness - There is a dependency on Public Blockchain

- Human resources required are blockchain experts

- Increased amounts of productive millennials

- The need for alternative financing

Opportunity alternatives to property

- The development of Blockchain community in Indonesia

- Increasingly expensive property prices

- Unclear regulations related to the use of blockchain technology

Threat - Limited human resources related to the development of blockchain

- Competitors that can duplicate business models

Source: Central Bank of Indonesia

An adequate strategy is required to ensure the company can run better and sustain. The key factors in the business development of this model are strongly affected by government regulations and also the availability of technology.

According to the regulation of $\mathrm{OJK}$, this business model need to joining regulatory sandbox(OJK, 2019). Joining will help OJK to understand the risk factor of the business, therefor it will help the authority to formulate suitable regulation for this kind of business models.

Good marketing strategies and education to the target market need to be done to ensure the community gets the basic idea of the business model and corporate vision. The more 
I Gede Putu Rahman Desyanta \& Gede Sri Darma / Development of Business Model Digital Fraction

Property Investment / JEE, Vol. 9, No. 2, September 2020, pp 111-122

understanding the community, the more will the community will consider join on this platform.

\section{DISCUSSION}

From the discussion conducted based on the interview data and the study of the library, the conclusion that can be taken are:

1. The use of Blockchain technology in business model ownership of a shared property has a scope in the transaction process and the possession of the digital asset that will be used as a property marker of ownership. Smart contracts are used in the transaction realm. The blockchain used is a public blockchain that assists in the confirmation of transactions with a large network. This can reduce the risk of data security in the network.

2. This business model is geared towards productive millennials and has a willingness to own property. The business of this model supports the building of the co-cumulative value of one property ownership. With a more affordable investment value, millennials who have a minimum wage can still invest in this platform. As a platform, the revenue streams are determined to be able to follow the rules of the government and still benefit to develop the company, then fee per transaction and also fee at each time the listing of the property will be the source of its income.

3. This business model has challenges in its implementation in relation to the technology used and the mechanism of ownership of digital assets. It is necessary to anticipate the current regulations in Indonesia in the use of Blockchain technology and also about property ownership and digital assets. To ensure the business runs long term, this business model needs to be re-analyzed to be developed with the appropriate regulation.

4. The business model is a simple and technological willingness in Indonesia, delivering the platform is vulnerable to be duplicated. It needs to be anticipated by the company with always innovating.

\section{REFERENCES}

Ahishakiye, E., Wario, R., \& Niyonzima, I. (2018). Developing Countries and Blockchain Technology/: Uganda's Perspective. International Journal of Latest Research in Engineering and Technology (IJLRET), 04(August), 94-99.

APJII. (2018). Penetrasi \& Profil Perilaku Pengguna Internet Indonesia Tahun 2018. In Apjii. Retrieved from www.apjii.or.id.

Budiati, I., Susianto, Y., Adi, W. P., Ayuni, S., Reagan, H. A., Larasaty, P., ... Saputri, V. G. (2018). Profil Generasi Milenial Indonesia. 1-153. Retrieved from www.freepik. com.

Casadesus-Masanell, R., \& Ricart, J. E. (2010). From strategy to business models and onto tactics. Long Range Planning, 43(23), 195-215. https://doi.org/10.1016/j.lrp. 2010.01.004.

Databoks. (2017). Pengguna Ponsel di Indonesia Mencapai $142 \%$ dari populasi. Retrieved from Katadata website: https://databoks. katadata.co.id/datapublish/2017/08/29/ pengguna-ponsel-indonesia-mencapai-142dari-populasi.

Databoks. (2019a). Berapa Jumlah Startup di Indonesia? Retrieved from Katadata website: https://databoks.katadata.co.id/datapublish/2019/01/14/berapa-jumlah-startupdi-indonesia\#. 
Databoks. (2019b). Jumlah Penduduk Indonesia 2019 Mencapai 267 juta jiwa. Retrieved from https://databoks.katadata.co.id/ datapublish/2019/01/04/jumlah-pendudukindonesia-2019-mencapai-267-juta-jiwa.

Fajar, M. (2017). Analisis Spektral Siklus Bisnis Indonesia. Working Paper, (November). https://doi.org/10.13140/RG.2.2.17045. 63208

Farrell, L., \& C., H. A. (2014). Training the Millennial Generation: Implications for Organizational Climate. CFA Digest, 44 (11), 47-60. https://doi.org/10.2469/dig. v44.n11.1.

Ibarra, D., Ganzarain, J., \& Igartua, J. I. (2018). Business model innovation through Industry 4.0: A review. Procedia Manufacturing, 22, 4-10. https://doi.org/10.1016/j. promfg.2018.03.002.

Karamitsos, I., Papadaki, M., \& Barghuthi, N. B. Al. (2018). Design of the Blockchain Smart Contract: A Use Case for Real Estate. Journal of Information Security, 09(03), 177-190. https://doi.org/10.4236/ jis.2018.93013.

Kartiasih, F. (2019). Inflasi dan Siklus Bisnis Politik di Indonesia. Media Trend, 14(2), 219-228. https://doi.org/10.21107/mediatrend.v14i2.4978.

Maritim, K. (2019). Presiden Resmikan Proyek Palapa Ring, Misi Pemerintah Satukan Indonesia Lewat Internet Tercapai.

Nakamoto, S. (2016). Bitcoin: A Peer-toPeer Electronic Cash System. Blockchain, 1-9. https://doi.org/10.1007/s10838-008-90620 .
Nielsen. (2020). Nielsen Corona Virus Survey Report Feb 24-29, 2020.

OJK. (2018). Peraturan OJK RI Nomor 13/ POJK.02/2018. Peraturan Ojk No.13, 129. Retrieved from http://www.ojk.go.id/ id/kanal/iknb/regulasi/lembaga-keuanganmikro/peraturan-ojk/Documents/SALPOJK PERIZINAN FINAL F.pdf.

OJK. Surat Edaran Otoritas Jasa Keuangan Tentang Regulatory Sandbox. 1 OJK $\mathbb{S}$ (2019).

Prasetyo, B., \& Trisyanti, U. (2018). Revolusi Industri 4.0 Dan Tantangan Perubahan Sosial. (5), 22-27. https://doi.org/10.12962/ j23546026.y2018i5.4417

Szabo, N. (1997). Formalizing and Securing Relationships on Public Networks. First Monday. Retrieved from https://firstmonday.org/ojs/index.php/fm/article/view/548/ 469.

Tirto.id. (2017). Kemana Mengalirnya Uang Para Millenials? Retrieved from https://irto.id/ ke-mana-mengalirnya-uang-para-milenialcv76.

Wang, H., Zheng, Z., Xie, S., Dai, H. N., \& Chen, X. (2018). Blockchain Challenges and Opportunities: a Survey. International Journal of Web and Grid Services, 14(4), 352. https://doi.org/10.1504/ijwgs.2018. 10016848.

Wikipedia. (2019). Kronologi Pendemi Corona Virus 2019-2020. Retrieved from Wikipedia website: https://id.wikipedia.org/ wiki/Kronologi_pandemi_koronavirus_ 2019-2020. 
I Gede Putu Rahman Desyanta \& Gede Sri Darma / Development of Business Model Digital Fraction Property Investment / JEE, Vol. 9, No. 2, September 2020, pp 111-122 